\title{
THE POLITICS OF PROTEST
}

\author{
THE GREAT STEEL STRIKE OF 1919-20 \\ IN LACKAWANNA, NEW YORK
}

On November 4, 1919, six weeks into the Great Steel Strike, the citizens of Lackawanna, New York, elected John H. Gibbons as their Mayor. Gibbons' victory was a major upset. He defeated John Toomey, the incumbent who had the support of the steel firm after which this quintessential company town was named, by forging a loosely knit coalition of native and Eastern European immigrant workers during the height of the xenophobia of the ongoing Red Scare. Gibbons' election came at a time when the Socialist Party was in decline and the various levels of American government enthusiastically used their repressive mechanisms to crush the country's "un-American" Left. ${ }^{1}$

Although Gibbons' election ran against the grain of the times, the event has escaped rigorous historical analysis. The sparse scholarship on the Socialist triumph fails to go beyond the obvious conclusion which sees Gibbons' election as a political reaction to the Great Steel Strike. ${ }^{2}$ This is

1 Resolutions to the question of whether or not the Socialist Party was on the decline ultimately hinge on the ideological nature of the party. Daniel Bell, for instance, views the pre-1920 Socialist Party as ideologically rigid and therefore alien to the American experience. James Weinstein, on the other hand, argues that prior to 1920 the Socialist Party was diverse and democratic with broad appeal to the masses. See Daniel Bell, "The Background and Development of Marxian Socialism in the United States", in: Socialism and American Life, ed. by Donald Drew Egbert and Stow Persons (Princeton, 1952), I, pp. 213-425; James Weinstein, The Decline of Socialism in America 1912-1925 (New York, 1967). Other pertinent works include Alan Wolfe, The Seamy Side of Democracy (New York, 1974), which gives a good general overview of the use of repression throughout the United States. Robert Murray, Red Scare (New York, 1971), also provides a good overview of the times. For an instance of red baiting and violence during the 1919 strike, see David Brody, Labor in Crisis (Philadelphia, 1965), pp. 147-78. Also, United States Senate, Committee on Labor and Education, Investigation of Strikes in the Steel Industry, Hearings, 66th Congress, 1st Session (1919), pp. 542-47, 603-07. For information concerning the repressive activities of New York state government during this period see Legislature, Joint Legislative Committee to Investigate Seditious Activities, Box 7, folder 33, New York State Archives, No 281.

2 Although David Brody does not analyze the Lackawanna experience, even he takes this position in his prescient work Labor in Crisis. More general works on the politics of 
unfortunate. For the Socialist electoral victory raises fundamental questions concerning the nature of the American working class in early twentieth-century industrial cities. Many historians view the cultural diversity of the working classes as the primary obstacle to the formation of class-rooted social and political movements. Ethnic, religious, racial and occupational cleavages, they argue, create distrust and suspicion among workers, leaving them isolated and exposed, susceptible to domination by more centralized corporate structures. Struggles between a fragmented workers' movement and centralized capital are not likely to end well for labor. Workers must, according to this perspective, transcend existing cultural schisms to form a unified and cohesive class-rooted movement capable of neutralizing the power of capital. ${ }^{3}$

This case-study of the Socialist electoral victory in Lackawanna attempts to analyze the dynamics underlying the formation and dissolution of one successful third-party protest movement. It is argued here that the Socialist protest in Lackawanna failed to overcome the cultural divisiveness of the city's steelworkers. Shaky and tentative at best, Gibbons' electoral coalition formed only after the incumbent Mayor captured the nominations of both the Republican and Democratic parties. The socialist victory was made possible when a number of small businessmen, angered by the Toomey administration's violent anti-labor activities, joined ethnic protestors and anti-Toomey Republicans in support of Gibbons' third-party candidacy as the only option "available to them within the limits imposed by their social circumstances". ${ }^{4}$ Even though conflicts between Eastern European ethnics and "American" workers continued throughout the strike and for decades thereafter, the social and cultural isolation of the new ethnics created a militant ethnic consciousness which thrust them into the

the Great Steel Strike include Commission of Inquiry, Interchurch World Movement, Report on the Steel Strike of 1919 (New York, 1920); United States Senate, Committee on Labor and Education, Report to the Senate on the Causes of the Steel Strike, 66th Congress, 1st Session (1919). Also, Walter W. Benjamin, "Bishop Francis J. McConnell and the Great Steel Strike of 1919-1920", in: A Miscellany of American Christianity: Essays in Honor of Shelton Smith, ed, by Stuart C. Henry (Durham, N.C., 1963), pp. 22-47. For a critique of the Interchurch World Movement Report see Marshall Olds, Analysis of the Interchurch World Movement Report on the Steel Strike (New York, 1922), pp. 189-209. For a balanced analysis of the two views see Phillip C. Ensley, "The Interchurch World Movement and Steel Strike of 1919", in: Labor History, XIII (1972), pp. 217-30.

3 For a discussion see Frances Fox Piven and Richard Cloward, Poor People's Movements (New York, 1977), pp. 96-180; Henry B. Leonard, "Ethnic Cleavage and Industrial Conflict in Late 19th Century America: The Cleveland Rolling Mill Company Strikes of 1882 and 1885", in: Labor History, XX (1979), pp. 524-48.

${ }^{4}$ Piven and Cloward, Poor People's Movements, p. 36. 
forefront of the anti-corporate protest and eventually re-shaped the city's political alignment. Gibbons' election provides us with important insights concerning the role of the political state and the fragmentation of the working class during periods of mass collective action. ${ }^{5}$

On May 24, 1900, the Lackawanna Iron and Steel Company of Scranton, Pennsylvania, began construction of a new steel mill in the rural town of West Seneca, New York. Situated on Lake Erie just south of Buffalo, the plant was heralded as the eighth wonder of the world, and in 1904 Iron Age referred to it as the world's largest steel mill. ${ }^{6}$ Just two years after workers broke ground for Lackawanna Steel's newest facility, the Rogers-Brown Steel Company erected a steel mill adjacent to the Lackawanna plant, and District 3 of the Town of West Seneca was dubbed, "Steeltown, U.S.A." At this point in the history of the steel industry, the experience of West Seneca was unique. In other steel centers the industry developed gradually over a period of years and the towns grew with the industry. In West Seneca, however, the world's largest steel plant was suddenly thrust upon a rural community barely three square miles in size, thus disrupting the tranquility of the township. The population of the Northwestern tip of West Seneca grew by leaps and bounds as the steel company hired thousands of workers, most of whom were newly arrived Southern and Eastern European immigrants. Between 1900 and 1907 the population of District 3 of the town tripled, and in 1909 the former lighting district of West Seneca was incorporated as the City of Lackawanna.?

Lackawanna's incorporation did not come easily. In fact, the struggle over incorporation reveals the convergence of interests between the controlling Democratic political organization of West Seneca and the Lackawanna Steel Corporation. When the steel firm moved to West

${ }^{5}$ For a discussion see Leon Fink, "The Use of Political Power: Toward a Theory of the Labor Movement in the Era of the Knights of Labor", in: Working-Class America, ed. by Michael H. Frisch and Daniel J. Walkowitz (Urbana, 1983), pp. 104-22; also, id., "Class Conflict in the Gilded Age: The Figure and the Phantom", in: Radical History Review, III (1975-76), No 1-2, pp. 56-72.

${ }^{6}$ For a short discussion of the early development of Lackawanna, see Lackawanna Bicentennial Commission, The History of Lackawanna (Lackawanna, 1976); E. F. Entwisle, "Development of the Iron and Steel Industry on the Niagara Frontier", mimeograph paper presented to the Buffalo Section Association of Iron and Steel Engineers, October 10,1944; Clara Whelan, "History of Lackawanna", unpublished manuscript, 1935, Lackawanna Public Library; Gertrude G. Schroeder, The Growth of Major Steel Companies, 1900-1950 (Baltimore, 1953).

7 The History of Lackawanna, p. 13 
Seneca, it brought along a number of skilled workers and supervisory personnel, most of whom were either native-born, or Irish, Welsh or German immigrants. ${ }^{8}$ Many of the predominantly English-speaking skilled workers viewed production as a co-operative endeavor and thus identified with management. This notion of an equal partnership between labor and capital was reflected in the "sliding scale", a method of compensating skilled workers. The company paid its skilled workers for each ton of steel they produced, and the amount of their remuneration fluctuated with the market price for iron and steel. The sliding scale tied wages of skilled workers to corporate profitability, and helped establish an identity between management and skilled workers. Many of these skilled "American" workers participated in the local Democratic Party and their numbers gave the party a pro-company flavor while helping it maintain control over the local political scene. Voter-registration methods also enhanced the Democrats' political dominance. According to state law, as long as the town remained unincorporated voters did not have to register in person. This enabled party officials to produce lists of unverifiable and, therefore, perhaps ineligible voters who supported the party ticket. Local Republicans, who constantly accused the Democrats of registering illegal voters from Pennsylvania, sought to end this practice by incorporating the steel district into a city. ${ }^{9}$ The steel company opposed incorporation for several reasons. Since many Democratic activists worked at the steel mill, a close identity existed between the party and the company. Incorporation threatened to reduce the clout of the local political machine by ending the practice of registering voters by lists. Additionally, incorporation would cost the company money. In 1904, for instance, a corporate spokesperson conceded that the plant was underassessed by about fifty per cent, and publicly stated that incorporation would increase the firm's tax burden. ${ }^{10}$

Underassessment reduced revenues and prevented the town from providing such basic services as gravel roads, sidewalks and sewers. This engendered political opposition, especially from within the small-business community, which organized around the issue of incorporation. As early as 1904 a group of eighty small businesses located within a half mile of the steel

8 Ibid., pp. 13-15; personal interview with Dr Joseph Kij, Lackawanna, August 24, 1982; personal interview with John Osborne, Lackawanna, August 11.

${ }_{9}^{9}$ In 1904 local Republicans were so concerned with this practice that they spent $\$ 2500$ to verify registration lists. It should also be noted that small-business interests supported incorporation because they felt abused by the Lackawanna Steel Company and wanted the steelmaker to assume a larger share of the tax burden. See Buffalo Express, January 18, 19, 23 and February 12, 1904; Buffalo Evening News, January 18 and February 12. ${ }^{10}$ Buffalo Express, February 12. 
plant petitioned for incorporation. The group's spokesperson, Michael Joyce, a saloon keeper who in 1919 would run an unsuccessful campaign as a Socialist candidate for the Lackawanna City Council, accused the Town Board of complicity with the steel company for failing to provide adequate services for small businesses, even though these firms paid more than $\$ 19,000$ annually in taxes. The struggle for incorporation finally paid off. In 1909 , after a major scandal led to the imprisonment of the West Seneca Town Supervisor for mishandling public funds, the company and the local Democratic Party yielded to public pressures for incorporation. Forced to accept incorporation, the steel firm used its influence to shape the destiny of the city it had created. Company attorneys wrote the first city charter and Lackawanna was incorporated as the smallest city in the state, about three square miles in size. To the chagrin of many small shopkeepers, the city's minute size still kept public expenditures down, maintained the plant's tax burden, and increased the company's influence in municipal affairs. ${ }^{11} \mathrm{~A}$ number of former activists of the West Seneca Democratic Party assumed important positions in the new government, and steel-firm officials, John J. Monaghan and Michael O'Mara, held the important positions of Tax Assessor and City Treasurer. ${ }^{12}$

Although the "old" immigrants dominated local government, Lackawanna was, above all else, a city of Eastern and Southern European immigrants. A 1911 United States Senate report on immigrants in industry stated that the chief significance of Lackawanna was that "it represents the growth of a large industrial population within recent years in connection with iron and steel establishments, made up principally of races of recent immigration to the United States." 13 In 1907, a year of normal production, some 16,000 of the city's 20,000 inhabitants were foreign-born with the vast majority $(13,300)$ consisting of Poles $(7,500)$, Hungarians $(2,000)$, Croations $(2,600)$ and sundry other Eastern European peoples $(1,200)$. Ninety per cent of the foreign-born men worked in the steel plants, thus prompting the General Superintendent of the Lackawanna Iron and Steel Company to state that his company could not have commenced operations in 1901 without immigrant labor.$^{14}$ The rapid influx of thousands of foreign workers

${ }^{11}$ For a discussion of the relationship between geographical and juridicial size and the influence of vested interests, see Grant McConnell, Private Power and American Democracy (New York, 1967).

12 Lackawanna Journal, July 6, 1909; The History of Lackawanna, p. 17.

${ }^{13}$ United States Congress, Senate, Immigrants in Industries, $\mathrm{Pt}$ II: Iron and Steel Manufacturing, I, 61st Congress, 2nd Session [Senate Document 633] (1911), p. 73 (hereafter referred to as Senate Document 633).

14 Ibid. 
created many social problems in a town unprepared for the disruptions of industrialization. Language differences and the tendency of new immigrants to settle in ethnic clusters obstructed communication among the sundry new ethnics and isolated them as a group from skilled Englishspeaking workers. Consequently, the new ethnics were often the objects of xenophobia and ridicule. ${ }^{15}$

The new immigrants' squalid living conditions reinforced the stereotype of the dumb, animal-like "Hunky". Although the Lackawanna Steel Company built 575 homes which rented at what the Bureau of Labor called reasonable rates ${ }^{16}$ native and old immigrant workers inhabited these dwellings. Foreigners chose to live in either hovels built on stilts in the swamps or with their kinsmen in the many multi-story boarding houses which dotted the landscape, even though municipal sanitary facilities were virtually nonexistent. ${ }^{17}$ The swamp served as a cesspool and garbage dump, further contributing to the extremely unsanitary conditions of these private homes. The consequences of the immigrants' squalid housing with their open sewers and exposed garbage are illuminated by the estimate of one doctor that in 1919 some sixty per cent of all immigrants were infected with tuberculosis. ${ }^{18}$ Since a divided labor-force is unamenable to organization, the steel plant's segregationist housing policies deterred unionization. But there were other implications to the pattern of ethnic isolation, which worked against the steel firm's interests. Segregation encouraged "new"

15 The term new ethnic refers to Eastern European immigrants, most of whom were not citizens of the United States and therefore could not vote. Although published United States Census data do not distinguish naturalized citizens by ethnic group, data do indicate that in 1910 eleven per cent of all male immigrants age 21 or over had become citizens. By 1920 some eighteen per cent had been naturalized and an additional twentythree per cent had filed their first papers toward naturalization. See Richard S. Sorrell, "Life, Work and Accumulation Patterns of Eastern European Immigrants in Lackawanna, New York: 1900-1922", in: The Polish Review, IV (1969), pp. 78-79; for a discussion of xenophobia see John A. Fitch, "The Human Side of Large Outputs, Steel and Steelworkers in Six American Cities: I, Lackawanna - Swamp, Mill and Town", in: The Survey, XXVII (1911), pp. 931-36; Buffalo Morning Express, March 26 and August 2, 1907; Buffalo Evening News, March 3; interview with Joseph Kij.

16 There were two clusters of company homes. Monthly rents in the new village (125 homes) ranged between $\$ 16.50$ and $\$ 19.50$, and in the old village ( 450 homes) between $\$ 6$ and $\$ 7.50$, depending upon the size of the facilities. United States Congress, Senate, Department of Commerce and Labor, Report on Conditions of Employment in the Iron and Steel Industry in the United States, III: Working Conditions and the Relations of Employers and Employees, 62nd Congress, 1st Session [Senate Document 110] (1913), p. 436.

${ }_{17}$ Fitch, "Lackawanna", loc. cit., pp. 934-35.

${ }_{18}$ Senate Document 633,p. 779. For another description of the squalid living conditions in the immigrant section of the city see Elizabeth S. Williams, "Clean Up Week in Lackawanna", in: The Survey, XXVIII (1912), pp. 561-62. 
ethnics to develop their own institutions independent of both the corporation and the city government. These institutions were crucial to the development and maintenance of an ethnically grounded anti-corporate consciousness.

Upon coming to Lackawanna, Eastern Europeans established churches where services were conducted in their native tongues. By 1919 the Poles had two churches in the first ward alone, and Serbians, Croats and Hungarians all had their own houses of worship. The Church played a significant role in educating the young. Poles, Hungarians, Croats and other Eastern Europeans combined to establish a large and prosperous Roman Catholic Church with its own parochial school, staffed by Polish nuns who conducted classes in Polish. Despite the poverty of immigrant steelworkers, they sent their children to church schools. Indeed, the city's two parochial schools had more teachers, larger enrollments and better equipment than the two public schools, which were attended primarily by native-born Protestants. ${ }^{19} \mathrm{~A}$ series of other social arrangements helped knit the new ethnics together. Almost half of the immigrant households had had boarders; by 1910 Eastern Europeans owned seventy-one of the city's small businesses; more than half were saloons where immigrants could socialize with their countrymen. Eastern Europeans also had the usual gamut of ethnic civic organizations, with the Poles having the largest and most active. $^{20}$

The new immigrants' social isolation and abysmal living conditions were virtually replicated in the factory. Between 1890 and 1920, as steel replaced iron as the backbone of industrial society, unskilled and semi-skilled steelworkers replaced the old ironmasters. Throughout the industry technological innovation de-skilled the labor-force, and the Lackawanna Iron and Steel Company was a leader in this area. Consequently, as unskilled labor replaced skilled craftsmen, immigrants swarmed to Lackawanna to fill the many low-paying, physically demanding, unskilled jobs, while native workers clung to the remaining skilled positions. By 1911 salaried workers and skilled craftsmen paid on the sliding scale, some twenty per cent of the plant's labor-force, were virtually all either native-born or of old immigrant stock. ${ }^{21}$ The segregation of Eastern European immigrants in unskilled jobs reproduced their living arrangements within the workplace.

19 Senate Document 633, pp. 791-92.

${ }^{20}$ Ibid., pp. 792-96.

${ }^{21}$ Entwisle, "Development of the Iron and Steel Industry", loc. cit., pp. 18-22, discusses Lackawanna Steel's innovations. See also F. G. Slagel, Sociological Director, Lackawanna Iron and Steel Company, to H. Shumway Lee, March 28, 1912, Buffalo and Erie County Historical Society; also, Sorrell, "Life, Work and Accumulation Patterns", loc. cit., pp. 74-76. 
Both at home and within the factory, they were physically divorced from native-born workers. This physical separation served to reinforce the psychological barriers between the two groups.

In the early twentieth century, working conditions in Lackawanna's steel industry were abhorrent. The work was physically demanding and extremely dangerous. ${ }^{22}$ Long hours and low pay characterized the existence of unskilled workers - those beasts of burden - at the bottom of the labor hierarchy.$^{23}$ In 1911, for instance, unskilled workers earned about fifteen cents an hour. On this basis, an unskilled laborer had to put in six twelvehour days a week for an entire year to earn $\$ 560$, the estimated minimal level of subsistence for a family of five.${ }^{24} \mathrm{But}$ this was not likely. Work in the mills was sporadic and most immigrants did not work throughout the entire year. In 1910 only twenty-five per cent of all foreign workers labored for a full twelve months, while nearly forty per cent of the native-born employees worked a full year. ${ }^{25}$

Despite such exploitation, foreign-born workers apparently remained docile employees. Many of these so-called "globe-trotting proletarians" came to the United States to work in the mills until they could earn their stake to buy farmland in the old country. The temporary nature of their American existence encouraged the new immigrants to tolerate the most abject living and working conditions. ${ }^{26}$ Yet there was some social mobility.

22 Buffalo newspapers reported numerous accidents in Lackawanna's steel plants during the period in question. Perhaps best encapsulating the public attitude toward safety, one newspaper described the death of a worker who was scalded by molten metal as "one of the risks that the steelmakers take". It continued by describing the horrors of what it called another of the accidents which appear to be unavoidable. Buffalo Express, August 2,1907 .

${ }^{23}$ The physically demanding jobs, low wages and abject living conditions of the foreign worker often reinforced the negative attitude of the native worker toward his foreign counterpart. According to some sociologists, the patterns of ethnic discrimination fostered, from a negative perspective, a sense of community among the immigrant population. Significantly, one study found that in the early 1920's Buffalo Poles felt they were subject to discrimination in greater proportion than any other ethnic group in that community. See Stefan Wolszczewski, "The Polish 'Sociological Group' in America", in: The American Slavic and East European Review, IV (1945), pp. 142-57; also, Niles Carpenter, Nationality, Color, and Economic Opportunity in the City of Buffalo (Westport, Conn., 1970), pp. 125-30.

${ }^{24}$ Sorrell, "Life, Work and Accumulation Patterns", p. 70; Fitch, "Lackawanna", p. 938.

${ }^{25}$ Senate Document 633, p. 763.

${ }^{26}$ For a good discussion of immigrant mobility see Brody, Labor in Crisis. Also, James R. Green, The World of the Worker: Labor in Twentieth-Century America (New York, 1980). This is not to suggest, however, that all immigrants suddenly decided to remain in the United States. During this period, there are numerous stories in the Buffalo press of the mass immigration of foreign workers. The fact remains, however, that following the 
At the onset of the First World War some ten per cent of the new immigrants held skilled positions at the steel plant, and a growing number moved away from the mill into the more affluent second and third wards, where they bought their own homes. The Poles, who as early as 1911 owned their own homes in larger proportions than any other ethnic group, including native workers, led the exodus away from the plant. ${ }^{27}$ The Great War accelerated the acculturation process and changed the immigrants' expectations of life in America. The war prevented many transient workers from returning home, thus forcing them to re-examine their commitment to America. Their prospects were enhanced when the Lackawanna Steel Company was awarded a hundred million dollars in government contracts. Indeed, the availability of work, higher wages and the federal government's more positive attitude toward unions provided incentives which encouraged many immigrants to remain in the United States after the war ended. ${ }^{28}$ Once committed to a permanent life in the USA, the workers' expectations changed drastically. What they formerly accepted as a temporary hardship was now part of their future prospects, but these prospects became less tolerable as the steel mill assumed a more permanent place in the immigrant's lives.

The permanently settled proletarians of Lackawanna's steel industry provided fertile ground for renewed efforts to organize the city's steelworkers. The post-war economic crisis, however, furnished the immediate impetus to unionization. Disarmament brought recession and, as steel orders declined, wages dropped and many workers lost their jobs. Since the

war the "globe-trotting" experience of the immigrants largely ended, and that most of those who remained in this country now had a permanent commitment. For a brief discussion, see Mrs Harry Sternberger, "Are Our Foreign-Born Emigrating?", in: The Survey, XLIII (1920), pp. 539-40. The disillusionment of the foreign worker is graphically captured in Mary Veaton Vorse, Men of Steel (London, 1922), pp. 183-85. ${ }_{27}$ Sorrell, "Life, Work and Accumulation Patterns", pp. 74-76; Senate Document 633, p. 799.

${ }_{28}$ Although labor unions gained about 2,000,000 new members during the war, the gains in the iron and steel industry were minimal. The advances achieved were largely the result of the policies of the War Labor Board, which made it difficult to fire workers for union membership. They were not the result of the organizational policies of the Amalgamated Association. Lewis L. Lorwin, The American Federal of Labor (Washington, 1933), p. 181; Raymond Patrick Kent, "The Development of Industrial Unionism in the American Iron and Steel Industry" (unpublished doctoral dissertation, University of Pittsburgh, 1938); H. E. Hoaglund, "Trade Unionism in the Iron Industry: A Decadent Organization", in: Quarterly Journal of Politics, III (1917), pp. 674-89. 
Lackawanna Steel Company had been a major government contractor, the city's economy was especially hard hit as the firm's earnings fell precipitously. In 1917, the steel corporation earned more than $\$ 20,500,000$ after federal taxes, but the cessation of hostilities in 1918 cut its earnings in half. Just as importantly, unfilled orders at the end of 1918 were also less than half those of the previous year. ${ }^{29}$

With the decline in orders, the company furloughed hundreds of workers, both skilled and unskilled. Those skilled workers fortunate enough to retain their jobs suffered wage cuts averaging about 36 per cent. A steep hike in the cost of living - it had jumped by 84.2 per cent between December 1914 and June 1919 - exaggerated the effect of plummeting wages and illuminated the serious plight of the city's steelworkers. ${ }^{30}$ The situation was further exacerbated when returning soldiers discovered that they had lost their old jobs in the mill. Having fought to make the world safe for democracy, returning soldiers took to the streets en masse to demonstrate peacefully against unemployment. ${ }^{31}$ The economic crisis reminded Lackawanna's steelworkers of the tentative and precarious nature of their existence at the plant. As wages dropped and unemployment climbed, the city's workers responded enthusiastically to the American Federation of Labor's efforts to organize the nation's steel industry. If, as President Wilson had argued, the recent conflict was a war for democracy, Lackawanna's steelworkers joined their co-workers across the nation in demanding the elimination of what they called "industrial autocracy" 32 in the United States.

Initially, the problem of organizing in Lackawanna differed from most other steel centers. Like other large steelmakers, the Lackawanna Iron and Steel Company had a long history of anti-unionism. But the Lackawanna firm grounded its anti-labor position upon a technology which relied mainly upon semi-skilled and unskilled labor. Indeed, the steel corporation utilized the most modern steelmaking technology available. The Lackawanna plant was the first in the United States to generate electric power through the use of blast-furnace gas engines; it relied upon electric motors to perform operations done in other mills by hydraulic power and steam-driven engines; it was the first steel plant in America to utilize regenerative by-product coke ovens; and its blast furnaces ranked among

${ }^{29}$ During World War I, Lackawanna Steel produced 4,500,000 tons for the war effort and earned $\$ 114,000,000$.

30 Buffalo Express, September 17, 1919; Monthly Labor Review, September, pp. 10810 .

${ }^{31}$ Buffalo Express, March 5.

32 Brody, Labor in Crisis, p. 73. 
the largest in the nation. ${ }^{33}$ The corporation's reliance upon modern technology de-emphasized the role played by highly skilled steelworkers. As the company recruited large numbers of untrained immigrant workers, who prior to the war were the most difficult segment of the labor-force to organize, the proportion of skilled workers employed in the plant declined. Since skilled workers traditionally were the chief organizational unit of the industry, their dearth in Lackawanna, combined with an abundance of unskilled immigrant workers, kept unions from gaining a foothold in the steel plant. ${ }^{34}$ By 1919 , however, technological innovation throughout the industry led to a general de-skilling of the labor-force, and, as unskilled workers replaced skilled, the American Federation of Labor's National Organizing Committee for Organizing the Iron and Steel Industry now targeted unskilled laborers as its primary organizational unit. ${ }^{35}$

The de-skilling of labor and the concommitant increase in the number of unskilled and semi-skilled employees undermined the position of older craftsmen, who viewed production as a co-operative venture. Technological innovations accompanied by declining wages and new modes of "managerial prerogative" upset the balance of power upon which the notion of co-operative production was based. This generated new schisms between management and skilled workers, many of whom joined the union as a means of protecting their craft. In Lackawanna, both unskilled and skilled workers answered the call for organization. To meet the demand for unionization, the National Committee called mass meetings where organizers extolled the advantages of unionization before distributing membership cards. According to William Z. Foster, the Secretary of the National Committee, "The idea was to make a hurricane drive simultaneously in all steel centers that would catch the workers' imagination and sweep them into the union en masse." 36

In the past, the steel company exerted sufficient control over its laborforce to prevent unionization. The proletarianization of the labor-force,

${ }^{33}$ Entwisle, "Development of the Iron and Steel Industry".

34 Although steelworkers were not organized, bricklayers and railroad workers were. For a discussion of the proletarianization of the labor-force see Katherine Stone, "The Origins of Job Structures in the Steel Industry", in: The Review of Radical Political Economics, VII (1974), pp. 61-97; also, David Brody, Steelworkers in America (Cambridge, Mass., 1960); Richard Edwards, Contested Terrain: The Transformation of the Work Place in the Twentieth Century (New York, 1979); Harry Braverman, Labor and Monopoly Capital (New York, 1974); David Montgomery, Workers' Control in America (New York, 1979).

${ }^{35}$ For a good analysis of the problems of organizing steelworkers along craft lines, see Hoaglund, "Trade Unionism in the Iron Industry", loc. cit.

${ }^{36}$ William Z. Foster, The Great Steel Strike and Its Lessons (New York, 1920). 
corporate welfare schemes, company housing, the isolation of the various ethnic groups, and the perpetuation of the myth of success through the occasional promotion of immigrant workers, ${ }^{37}$ all fragmented the laborforce while placing the worker in a position of extreme dependency. But the company's past success in preventing unionization now undercut its ability to do the same in the future. Unlike their counterparts in the Pittsburgh district, Lackawanna's steelworkers had not experienced broken strikes, and abortive labor struggles were not part of their consciousness. ${ }^{38}$ The economic and social changes of the post-war period, combined with the absence of futile strike experiences, increased the workers' militancy and forced the company to resort to stronger tactics to prevent unionization.

Although workers of diverse backgrounds and abilities - skilled and unskilled, foreign and native-born - responded to the organizational drive, the close relationship between the governing Democratic Party and the steel plant did not augur well for the union. As organizational efforts gained momentum, the company relied upon its allies in government to help squelch the nascent labor movement. By 1919 Lackawanna Steel had some important allies: the Mayor and the entire four-person City Council were Democrats sympathetic to the company's needs. In fact, in 1917 the Mayor, John A. Toomey, a real-estate man, and first ward Councilman Bernard McDonnell, a steel-plant employee, were publicly denounced as steel company dupes by Charles Ellis, the editor of the Lackawanna Journal. ${ }^{39}$ Another Councilman, Fred Nelson, was a supervisor in the Lackawanna railroad yards. The other two members of the Council, Martin Doherty and James Barrett, did not work at the plant, but were long-time activists in the Democratic Party.

Led by Mayor Toomey, Lackawanna's governing officials expressed their pro-company sentiments by supporting the company's anti-union efforts. Toomey placed restrictions on the right to assemble and prohibited organized labor from meeting in the city. Workers had to meet in neighboring Buffalo, where union rallies were confined to two meeting halls, neither of which was big enough to accommodate large crowds. When the workers eventually overcame this obstacle, the company took more drastic steps. In

\footnotetext{
37 There was some limited upward mobility among unskilled workers at the Lackawanna plant. For a discussion see Sorrell, "Life, Work and Accumulation Patterns", pp. 74-76. ${ }^{38}$ For a discussion of the role of consciousness of past failures as a contributing factor in the failure of the strike, see Robert Asher, "Painful Memories: The Historical Consciousness of Steelworkers and the Steel Strike of 1919', in: Pennsylvania History, XLV (1978), pp. 61-79. For an overview of the attitude of workers outside the Pittsburgh area toward the actions of the Pittsburgh workers, see David Saposs, "In the Wake of the Big Steel Strike", in: Labor Age, III (1923), p. 7.

${ }^{39}$ Lackawanna Journal, September 22 and October 6, 1917.
} 
August 1919 the plant discharged close to 1,000 men who had heard union organizer William $\mathrm{Z}$. Foster extol the virtues of unionization in the steel industry. ${ }^{41}$ It soon became apparent that the firings only reinforced the workers' support for the National Committee's organizing drive. Just three days after the massive dismissals, on August 28th, several thousand steelworkers participated in the largest American Federation of Labor rally ever held in Buffalo. ${ }^{41}$

Despite attempts by the company and governing officials to stop it, the union drive continued to snowball. On the 13th of September Lackawanna's steelworkers formed the Loyalty Lodge of the Amalgamated Association of Iron, Steel and Tin Workers of North America. Eastern Europeans, particularly Poles, dominated the local union leadership: Vincent Mach was President; Frank Mazur, Vice-President; George Beres, Financial Secretary; Waurzeniec Musial served as Recording Secretary; Sam Hyreck was appointed as Guide; Sylvester Wanteh was the Journal Agent; and the Trustees consisted of Konstantz Nobozny, Virgie Bonarck and John Kozub. ${ }^{42}$ Four days later Lackawanna's newly organized workers voted to support the national strike scheduled for September 22.

City officials immediately responded to the strike vote. Declaring the forthcoming strike to be the unpopular work of the foreign Bolsheviki of the first ward, Mayor Toomey vowed to back the company's efforts to keep the plant open. In what Major Chandler of the New York State Constabulary described as the excited condition of local officials ${ }^{43}$ the Toomey administration helped the steel company convert its plant into an armed camp. While the corporation was hiring additional private detectives and arming them with machine guns, bayonets, clubs and other military gear, ${ }^{44}$ city officials recruited extra police and invited the local American Legion

${ }^{40}$ It is virtually impossible to determine the exact number of workers terminated. The company claimed only 600 were dismissed; other reports had as many as 3,000 being fired. See Buffalo Express, August 26, 1919, and Lackawanna Daily Journal, August 25. There are numerous other reports of Lackawanna Steel's use of spies and other forms of intimidation to prevent unionization, but conclusive documentation does not exist. A number of works have documented such practices by other companies in other towns. See, for instance, Charles A. Gulick, Labor Policy of the United States Steel Corporation (New York, 1927), pp. 111-37; also, Commission of Inquiry, Interchurch World Movement, Public Opinion and the Steel Strike (New York, 1921), pp. 1-86.

${ }^{41}$ Lackawanna Journal, August 28, 1919.

42 Amalgamated Journal, October 2.

${ }^{43}$ Major George F. Chandler of the New York State Constabulary to Governor Alfred E. Smith, September 22, Governor Alfred E. Smith Papers, Box 260, file 168, New York State Archives. All citations of Smith Papers are taken from this file. Also, Buffalo Express, September 22.

${ }^{4}$ Buffalo Express, September 21. 
Post to help maintain law and order. Police Chief Ray Gilson added fuel to the fires of hysteria by boasting that he had 1,200 guns which could be used to protect property and keep the peace. ${ }^{45}$

At first blush it appears that Mayor Toomey's strong anti-union position was a politically clumsy move; facing re-election in November, the Mayor needed the steelworkers' support. ${ }^{46}$ But company towns are not seedbeds of democracy and the reality of power in such places is often quite different from its formal appearances. ${ }^{47}$ Lackawanna was no exception to this rule. Indeed, contemporary newspaper accounts lucidly describe the patterns of interdependence between the corporation and the city government. According to reports in the muckraking Lackawanna Journal, the Mayor encouraged the steel plant to dismiss employees for union activities, because they would be replaced only by workers whom he recommended to Harry J. Kelly, the Superintendent of the rail mill at Lackawanna Steel and city tax assessor. ${ }^{48}$ While this symbiotic relationship was a bane to workers, it benefited both the local political machine and the corporation. The Mayor dispensed jobs at the mill in return for votes. This, of course, added to the power of the local political machine by increasing the patronage which held it together. To ensure Democratic electoral success, steelcompany officials sometimes escorted workers to the polls to vote the so-called company ticket. ${ }^{49}$ The steel firm benefited from this by gaining a seemingly endless supply of non-union labor, while securing the favor of the city on those matters which it deemed important including, among others, tax assessments, contributions toward road repairs, etc. ${ }^{50}$

${ }^{45}$ Mayor Toomey to Governor Alfred E. Smith, September 19, Smith Papers; also, Buffalo Express, September 21.

46 Toomey might very well have underestimated the strength of the union because representatives of the steel company predicted that only 15 per cent of the workforce would strike. Still, the huge turnout at union rallies, despite strictly imposed controls by the police, should have alerted the Mayor to the inaccuracy of the company's predictions. 47 The political clout of steel plants in medium-sized company towns has been described by the Bureau of Labor in the following terms: "So completely are the people, as well as the business activities of most of the 'steel town' dependent upon the local steel plant that any proposal made with the sanction of the company would be carried out if within the powers of the community." Report on Conditions of Employment in the Iron and Steel Industry, III, p. 472.

48 Lackawanna Journal, August 27, 1919.

49 Ibid, , August 23 and September 23.

50 Charles Ellis, publisher of the Lackawanna Journal, printed a number of stories suggesting corruption between the steel plant and the Toomey administration concerning workers' compensation cases. See ibid., August 23, 25, 27 and September 3. The Journal's charges of collusion between the steel company and the city government were corroborated by statements of steelworkers and others close to the strike. An assistant superintendant in Lackawanna Steel's open-hearth department told interviewers that the 
Admittedly, direct evidence in support of the charges against Toomey remains inconclusive. But, as revealed in Bertha Saposs' post-strike interviews, many native workers also viewed the Mayor as a company tool. ${ }^{51}$ Toomey's successful efforts to gain the backing of both political parties lends further credence to this view. Apparently anticipating a reaction against his anti-labor policies, Toomey also sought the Republican nomination, even though Democrats outnumbered Republicans by more than a 2-to-1 margin. ${ }^{52}$ Aided by a sixty-percent turnout, in early September the incumbent Mayor won a plurality of 133 of the 299 votes cast in a three-way fight for the Republican nomination. Charles Ellis, one of Toomey's opponents, attributed the Mayor's victory to massive lay-offs at the plant and charged the Mayor with collaborating with the steel company in gaining votes of steelworkers in the city's first ward. Toomey also regained the Democratic nomination by a wide margin, and Buffalo newspapers assured the public that the Mayor would be re-elected. Unrestrained by electoral considerations, the Mayor appeared to have carte blanche to crush the forthcoming strike..$^{53}$

Mayor Toomey may have thought his primary victories guaranteed his re-election, but he was mistaken if he believed they represented a mandate for his anti-strike activities. Reaction to Toomey's "armed camp" approach came fast. On the eve of the strike, the newly formed American Legion Post turned down the Mayor's request to help police the city during the strike. Many members of the Legion were steelworkers sympathetic to the union and they rebuffed the Mayor, even though they had a request for $\$ 45,000$ to erect a new clubhouse pending before the city government.$^{54}$ The wisdom of the Legion's position was proved the following day when, to almost everyone's surprise, the strike was about 98 per cent effective. This prompted the president of Lackawanna Steel, who previously predicted

company had been running the town to suit itself. Others accused Toomey of being a company tool. See Bertha Saposs, interviews with Mr Vetter, Mr Dougherty and "Man on Perch"; also, statement of John R. Commons, David J. Saposs Papers, Box 26, file 5, State Historical Society of Wisconsin.

${ }^{51}$ Statement of John R. Commons.

52 Enrollments for 1919 showed the Republicans with 494 to the Democrats 1,298; the Socialists had but 52. Erie County and Buffalo Board of Election, Registrations and Enrollments, 1917-21.

${ }^{53}$ Buffalo Express, August 26 and September 3, 1919; Lackawanna Journal, September 3.

${ }^{54}$ Buffalo Express, September 20. 
that only about 15 per cent of the workers would strike, to concede that the walk-out was complete. ${ }^{55}$

The effectiveness of the strike only hardened the position of the city's fathers. With thousands of striking steelworkers roaming Lackawanna's streets, the Mayor ordered the police to break up any gatherings of twelve or more strikers. The State Constabulary supported Toomey's hard-line approach. Speaking in support of Toomey's position, Captain W. W. Robinson exacerbated an already dangerously tense situation by proclaiming that he and his men "will use our clubs freely and our guns if we are forced to it." 56 To the chagrin of municipal leaders and steel-firm officials, the threats of arrest and violence failed to intimidate the strikers. On Tuesday, September 23, three thousand strikers and their families gathered outside Gate Three of the Lackawanna Steel Plant.

Exactly what followed has never been officially determined. But newspaper reports and eyewitness accounts agree that when the crowd began to throw stones at two of the steel company's policemen as they left the plant, guards fired shots from inside the walls of the mill. Bullets killed one striker, fatally injured another and wounded at least two other individuals, including a young child. Casimer Mazurek, a 24-year-old Polish American World War I veteran and a member of the local American Legion, died of bullet wounds to the head. Maciez Buczkowski, the fatally wounded striker, was a Polish citizen. ${ }^{57} \mathrm{He}$ died two days later. Immediately after the shootings, Charles $\mathbf{H}$. McCullough, Jr, President of the Lackawanna Steel Company, announced the closing of his plant. In his statement, McCullough accused "foreigners" and radicals of using violence to intimidate loyal American workers.

It now appears that the organizers sent to Lackawanna have been successful in enlisting the support of many foreigners and a few radicals, and these, through intimidation carried to the homes of the American Workman, have created such a condition that the management does not feel warranted in asking the loyal men to take the personal risks involved in entering the plant. ${ }^{58}$

The public's response to the shootings blocked McCullough's attempts to blame foreigners for using violence. Support for the strike came from all

55 Ibid., September 24; Buffalo Evening Times, September 23.

56 Buffalo Evening Times, September 21.

57 For accounts of the shootings see ibid., September 25; Lackawanna Journal, September 23; Buffalo Express, September 24; also, Foster, The Great Steel Strike, op. cit., pp. 183-84.

58 Buffalo Express, September 24. 
sectors of the population, and many viewed the hard line taken by Toomey as the motive force behind the violence. Strike organizers protested the violence and claimed that the Mayor's unwillingness to let the strikers meet in the city led to the shootings. ${ }^{59}$ This served to solidify the ranks of the strikers and their families, seven thousand of whom joined the funeral procession of Casimer Mazurek, the first strike victim. Ironically, the procession for this twice decorated hero of World War I proceeded past the City Hall, which was blazoned with a sign welcoming home the city's war heroes. Governing officials further aggravated the already tense situation when they prohibited the playing of "Taps" at Mazurek's grave. The Buffalo Evening Times touched upon the anger of the people of Lackawanna when it described the largest funeral ever held in Lackawanna as a "protest against the wanton killing of a returned soldier". ${ }^{60}$

The subsequent handling of the shootings by the authorities further strengthened the strikers' resolve. Despite statements by eyewitnesses, including a private guard employed by the steel company, that they could identify the assailants, the police failed to charge anyone with the shootings. The chief of the steel company's private police refused to submit the names of the guards stationed at Gate Three on the day of the shootings, and Police Chief Gilson admitted at an inquest that he did not make an investigation to determine who killed the two strikers. The failure of local authorities to charge anyone with the attack led the American Legion Post, of which the slain Mazurek was a member, to send a resolution requesting an investigation to the Erie County District Attorney. ${ }^{61}$ Weeks later, after no arrests were made, the Polish government instructed its Consulate in the United States to investigate the shooting of the second victim, Maciez Buczkowski. All this proved futile, as no one was ever charged with the crimes. ${ }^{62}$

If the circumstances surrounding the shootings and the failure of the authorities to apprehend the killers solidified the workers' resistance against the plant and local authorities, subsequent actions by the authorities only increased the possibility of further violence. The city and state govern-

59 Ibid., September 26; Buffalo Evening Times, September 26.

60 Buffalo Evening Times, September 26; Amalgamated Journal, October 2; also, Bertha Saposs, interviews with Vetter and Dougherty.

${ }^{61}$ Buffalo Express, September 28; Buffalo Evening Times, September 29; Lackawanna Journal, October 1.

62 As of May 7, 1921, the steel company paid some $\$ 17.000$ in damages to the families of the slain strikers. No one was arrested for the shootings. For a more complete description see Lackawanna Journal, May 7, 1919. Foster claims the company made out-of-court settlements in addition to those made on the shootings, The Great Steel Strike, pp. 18384. 
ments relied even more upon the use of their repressive powers to break the will of the strike. While no one was charged with killing the strikers, fifteen members of the crowd which was fired upon were arrested for inciting a riot. The state constabulary replaced Captain Robinson with an officer who had witnessed the shootings, Lieutenant John Sheehan, and the troopers increased their forces by an additional 75 men. Lackawanna took on the look of an occupied city on the verge of martial law. Tavern keepers were told that they would be closed if they allowed strikers to talk of rioting, and the troopers joined with regular city police and special deputies by imposing what became known as a "reign of terror" upon the people of Lackawanna. ${ }^{63}$ Almost immediately after the shootings, the police closed off roads near the plant and began to search all "suspicious looking" strikers. Eastern Europeans were targeted for special treatment. Some were singled out for arrest merely because they did not speak English; others were frequently harassed by the police ${ }^{64}{ }^{6}$ Dozens of Eastern European strikers and their families complained of being chased by police on horseback, and there were numerous reports of troopers riding their horses into taverns and stores to intimidate workers. ${ }^{65}$

The evidence also suggests that the police physically beat Eastern European strikers and their families. Several Polish women signed affidavits alleging that the police struck them in the presence of Lieutenant Sheehan and Chief Gilson. One woman gave birth just nine days after the troopers beat her ${ }^{66} \mathrm{~A}$ report from Sheehan to his commanding officer in Albany clearly expresses the attitude of the authorities towards the free use of violence against foreigners. Describing the arrest of a woman "rioter", Sheehan wrote: "Trooper Shults was busy beating the heads of a few men who were trying to rescue the woman from Trooper Cozart." ${ }^{\text {"h7 }}$ Another report from Trooper Superintendent Dutton to Governor Alfred Smith states that the constabulary behaved moderately, even though one woman

${ }_{63}$ Buffalo Evening Times, September 25; Buffalo Express, October 1; Lackawanna Journal, October 24.

6t The case of Agnes Woloszyn provides some clues as to how the nativist reaction was used against Eastern Europeans during the strike. Woloszyn and several other women were stopped and questioned by Police Chief Gilson. Woloszyn, the only member of the group who did not speak English, was held while the others were set free. See affidavit of Agnes Woloszyn, November 14, Smith Papers.

${ }_{65}$ For a sampling of alleged incidents involving troopers and their horses see affidavits of Jennie Rykata and Mary Kurzon, signed November 14, and of Carolina Ciolek and Apolonia Jablonska, signed November 22; also, Lieutenant E. J. Sheehan to Superintendent of New York State Police, November 9, ibid.

66 Affidavit of Teresa Wawryszewicz, signed November 22, ibid.

67 Lieutenant E. J. Sheehan to Superintendent of New York State Police, November 9. 
had her arm broken and troopers had to fire some shots. ${ }^{68}$ Indeed, the police apparently used whatever force they had at their disposal. Within a month after the initial shootings, their bullets had felled three more strikers.

Repression was everywhere in Lackawanna and union officials were prime targets. Police vowed to hold labor organizers responsible for the acts of the strikers. These were not mere threats. One evening police dragged Vincent Mach, the President of the Loyalty Lodge of the Amalgamated Iron and Steel Workers, from his bed and charged him with conspiring to blow up a railroad bridge. Mach filed a countersuit alleging that Chief Gilson had beaten and arrested him without reason. In initiating the suit, Mach's attorney said, "There have been so many instances of action of this kind by the police that we have begun this suit to have them stopped." 69 Mach's litigation did not stop the police, but the New York Court of Appeals eventually ruled in his favor. ${ }^{70}$

The constabulary's use of force was not always unprovoked. Although strike organizers urged the workers to refrain from using violence, emotions ran high and the strikers often fought back. There were numerous reports of strikers' wives terrorizing the hated scabs, and trolley cars carrying strikebreakers to the plant did not always proceed unmolested. On several occasions trolleys were attacked by mobs of angry women and at least one was overturned. Even the president of the Board of Education, a strikebreaker employed by Lackawanna Steel, was badly beaten by striking steelworkers. ${ }^{71}$

Violence by the police often spawned new violence by the strikers, which in turn set the entire process off again. But Lackawannians also responded in more peaceful ways. There was a strong political reaction to the presence of the state constabulary. The troopers symbolized the public authority's anti-strike position, and strikers blamed Mayor Toomey for inviting the troopers to Lackawanna. Other segments of the population picked up on the charge and carried its logic a step further. A large segment of Lackawanna's small-business community, for instance, perceived a close nexus between the company's anti-labor policies and local political struggles over municipal services and corporate-tax assessment. Indeed, while

${ }_{68}$ Deputy Superintendent Dutton of New York Constabulary to Governor Alfred E. Smith, November 8, Smith Papers.

${ }^{69}$ Lackawanna Journal, October 30.

70 It is significant to note that Gilson's defense attorney was also employed as counsel for the Lackawanna Iron and Steel Corporation.

${ }^{71}$ Lackawanna Journal, October 22; Deputy Superintendent Dutton to Governor Alfred E. Smith, November 8. 
in many other steel centers small-business interests opposed the strike, the excesses of police drew the wrath of Lackawanna's small-business community. Operating on the premise that if Toomey had invited the state constabulary to Lackawanna he could also ask them to leave, local entrepreneurs, more than seventy of whom were Eastern Europeans, frequently extended credit to the strikers and circulated a petition requesting the Mayor to remove the troopers and to limit the activities of Lackawanna Steel's private detectives to the confines of the steel plant. ${ }^{72}$ Toomey's credibility received a jolt when, after publicly denying that he had invited the troopers to Lackawanna, the pro-union Lackawanna Journal printed copies of correspondence between Toomey and Governor Smith which revealed that the Mayor did indeed ask Smith to send the constabulary to Lackawanna. ${ }^{73}$

John Gibbons, the Socialist candidate for Mayor, focused his campaign on the close relationship between Toomey's anti-unionism and the so-called "reign of terror". The Socialist challenger, a long-time supporter of union causes, channeled the growing adverse sentiment for the Toomey administration into support for his candidacy by identifying "union busting" with police intervention. After arguing that anti-labor policies dictated the use of violence, Gibbons assured the public that armies would not be needed if workers had the right to organize. Whether exhorting workers at their meeting place, the Dom Pulski Hall, or using the Lackawanna Journal as his forum, Gibbons promised to use the full powers of the Mayor's office to promote unionism. ${ }^{74}$ This, he stated, would include giving organized labor the right to meet in Lackawanna.

If Mayor Toomey's reign of terror furnished Gibbons with an effective election issue, it also provided the impetus for steel-plant officials to launch their own offensive against the strike. Steel executives viewed the Mayor's willingness to unleash the police against striking steelworkers as an invitation to crush the strike, and in mid October they began to prepare for the

72 Petition signed by 38 of Lackawanna's small businessmen submitted to Governor Alfred E. Smith, October, Smith Papers. There was also a newspaper account of another petition with fifteen signatures favoring Toomey's actions. While no copies of this petition are available, it was discussed during a regular meeting of the Lackawanna Common Council. See Minutes, Lackawanna Common Council, January 19, 1920.

73 Lackawanna Journal, October 25, 1919.

74 Report, Agent M. F. Blackmon, November 28, Bureau of Investigation, file No OG 790720, Microfilm Reel 184 B, National Archives; Lackawanna Journal, October 20; also, Assistant Director and Chief Bureau of Justice to Brigadier General M. Churchill, Director of Military Intelligence, War Department, November 13 (unsigned), Bureau of Investigation, loc. cit. 
resumption of production. In their efforts to intimidate workers, company officials paraded Negro strikebreakers through the city in military fashion, evicted some 200 skilled workers from company housing - including Bernard McDonnell, the Democratic City Council man from the first ward -, and threatened to raise the rents of other recalciltrant workers. The steel firm supplemented its coercive policies with positive sanctions by offering bonuses to strikers who crossed picket lines and returned to work. ${ }^{75}$

The discipline of fear and hunger took its toll. After several payless weeks workers began to pour across the picket lines. By late October some 2,000 strikers, about one-third of the city's steelworkers, had returned to the mills. Although exact numbers are not available, according to newspaper accounts, Bureau of Investigation Reports and observations by the New York State Constabulary the strikebreakers consisted largely of imported scabs from outside the area and English-speaking workers. David Brody, for instance, estimates that some 2,000 Negro strikebreakers were brought to the Buffalo area during the course of the Great Steel Strike. To the chagrin of anti-labor observers, Eastern Europeans, led by the Poles, remained out. Even though it was weakening, the strike would not break unless the new ethnics returned.

On November 4, with the strike threatening to collapse, voters flocked to the polls in record numbers to elect Socialist John Gibbons Mayor. Gibbons, who just two years earlier received only 9 per cent of the vote in a losing race for a seat on the City Council, won the election by 27 votes, 996 to 969 . The only Socialist elected to office in Lackawanna, the Mayor elect carried the first, second and third wards by 130 votes, winning 54.4 per cent of the total vote. Gibbons lost the rural fourth ward by 103 ballots, taking only about 36 per cent of the vote cast there. Although the Socialist Party ran candidates for the City Council in the second, third and fourth wards, all were soundly defeated. The third-ward candidate garnered 37 per cent of the vote, while his counterparts in the second and fourth wards received only 17.1 and 7.1 per cent of the vote, respectively.

The 1919 Lackawanna elections suggest the continued existence of the old-ethnic/native split. Gibbons won the election by getting the votes of anti-Toomey Republicans who had no place else to go, registered Socialists, new-ethnic protestors, and some skilled native and old-ethnic protestors. It is not clear how many skilled English-speaking workers supported Gibbons, since this group was clearly divided on the mayorality campaign.

${ }^{75}$ Lackawanna Journal, October 8; Buffalo Express, October 11. See also Bertha Saposs, interviews with Mrs Cummins and Mrs Dornin; Brody, Steelworkers in America, op. cit., pp. 254-55. 
Many had crossed picket lines, others stayed out. In fact, as noted above, the steel firm had even evicted about 200 skilled workers, including Bernard McDonnell, from company homes. In other races, however, the internal split among the Democrats was virtually non-existent. Democrats carried all four City Council seats, despite the fact that in other places Socialist candidates almost always did better as the size of the electoral unit decreased. The anti-Toomey sentiment of traditional Democrats did not rupture the native-born-old-ethnic Democratic alliance. Gibbons' election was a protest aimed at Toomey's violent anti-labor activities and shaped by the temporary collapse of the local two-party system.

Although precise numbers are unavailable, it is readily apparent that the vast majority of Lackawanna's voters worked in the city's steel plants. According to available data, in 1919 Lackawanna's steel mills employed approximately 6,000 workers. The city's adult male population, including the sick, aged and infirm fifteen years of age and older, was 6,227, and, since the industry employed only a handful of female workers, it is safe to assume that most voters or their spouses worked in the local steel industry. This was especially true for immigrant workers who came to this country to work in the mills. ${ }^{76}$

This is not to suggest that Lackawanna's Socialist Party consisted primarily of steelworkers. On the contrary, support for the party traditionally came from skilled railroad workers and progressive elements of the petty bourgeoisie, whose interests clashed with those of the steel company. John Gibbons, after all, worked as a locomotive engineer, and the Socialist candidates for the City Council for the second and third wards also toiled in the New York Central railroad yards. In 1919, the Socialists failed to enter a council candidate in the first ward, but Michael Joyce, a first-ward tavernowner, ran for a seat from the fourth ward. Joyce's candidacy symbolized the role played by the organized progressive elements of Lackawanna's middle class. Until 1919, the Socialist Party drew its support from a narrow base of the city's population; the strike, however, angered many steelworkers, who expressed their anti-corporate hostilities by supporting Gibbons.

${ }^{76}$ This estimate is based on information compiled from the following sources: Senate Document 633, p. 733; various editions of the Lackawanna Journal, the Buffalo Express and the Buffalo Evening News for 1919; Foster, The Great Steel Strike; Report, Agent M. F. Blackmon, November 1, Bureau of Investigation, loc. cit.; United States Census Office, Fourteenth Census of the United States Taken in the Year 1920 (Washington, 1922), III, p. 33. It should be noted that an unidentified number of steelworkers lived in Buffalo and could not vote in Lackawanna. The evidence indicates, however, that their numbers were not sufficient to distort the present findings. 
The extremely high voter turnout in 1919 attests to the anger of the steelworkers. Indeed, in 1919 voter turnout reached a new high of 2,423, compared with 1,618 just two years earlier ${ }^{77}$ This lends further credence to Gibbons' victory as a protest against the anti-labor policies symbolized by Mayor Toomey. Additionally, the number of voters refusing to vote for either candidate doubled, jumping from 225 blanks on the mayoral line in 1917 to 468 in 1919. The large number of blanks in the mayoral race indicates that many voters, although reluctant to cast their ballots for a Socialist, refused to support the incumbent. If these voters formerly backed Toomey, their refusal to vote in the mayoral race also constituted a protest and indirectly assisted in Gibbons' campaign.

It should also be noted that Gibbons carried each of the city's three ethnic wards. Some 99.2 per cent of Lackawanna's alien population, which in 1920 consisted of 44.8 per cent of the city's total population, 21.2 per cent of whom were either Polish (44.7 per cent of all foreign-born residents), Hungarian, Yugoslavian, Rumanian, Czechoslovakian or Lithuanian, lived in the first, second or third wards. ${ }^{78}$ Gibbons' margin of victory in these three wards was 130 votes, the bulk of which came from the third ward, which he carried by 114 ballots. This more than offset his 103-vote deficit in the "American" fourth ward.

The ethnic and occupational background of the inhabitants of the residential third ward did not differ distinctly from the city's second ward, which went to Gibbons by 6 votes, with the exception that a greater number of first-generation Americans of Polish descent apparently lived there, and the proportion of registered Republicans was higher in the third ward. Indeed, although Democrats outnumbered Republicans by nearly a 5-to-2 margin throughout the city as a whole, in the third ward the number of registered Republicans (152) almost approximated the number of Democrats (179). Moreover, the political experience of the third ward differed significantly from that of the first, second and fourth wards in that the thirdward candidate for the Council, Fred Nelson, had emulated Mayor Toomey in securing both the Democratic and Republican nominations. Thus the anti-corporate, Republican vote had no other place to go than to support

$\pi$ By 1919, women had gained the right to vote in New York State, and this contributed to the increased turnout in Lackawanna. Yet, the data indicate that only 505 women registered to vote in 1919 . Even if all 505 voted, which is unlikely, their participation does not in itself explain the great increase in voter turnout. See official canvas for Erie County, General Election, November 4, 1919, Erie County and Buffalo Board of Elections, Registrations and Enrollments, Special Enrollment for Women, May 1918. ${ }^{78}$ Fourteenth Census of the United States, III, p. 56; also, Report of the Secretary of State on the Enumeration of Inhabitants, 1915 (Albany, 1916), pp. 1243-51 
the Socialist candidates. This helps explain Gibbons' victory and the fine showing of the Socialist candidate for City Council. Also important is the fact that more grown children of Polish immigrants apparently lived in the third ward. The children of immigrants are more likely to have mastered the language and probably understand the issues better than their foreign-born parents. ${ }^{79}$ This, in combination with the higher occupational status of their native-born offspring, a characteristic of both the second and third wards, and the gradual movement of these workers into the middle class, translates into higher levels of political participation. In this sense, the evidence suggests that the protest was led by Eastern Europeans, primarily the Poles and their American-born progeny, who attempted to consolidate their gains and realize their higher expectations at the plant through direct political action against the Toomey-run political machine.

When Woodrow Wilson asked a Socialist Mayor of a small town in Nebraska if his election meant that the town was socialistic, the Mayor responded by stating that the vote by which he was elected "was about 20 per cent socialistic and 80 per cent protest." ${ }^{\circ 0}$ While this description also applies to Gibbons' election in Lackawanna, the nature of the protest raises important questions concerning the possibilities of forming class-oriented movements in the United States. The evidence suggests that Gibbons' election failed to overcome the old schism between English-speaking workers and new ethnics. Old ethnics and native workers crossed picket lines in far greater proportions than Eastern European workers. Moreover, the abysmal showing of other Socialist candidates combined with Democra-

79 Although, again, precise data are not available, analysis of New York State Manuscript Census data for 1915 and 1925 reveals that a large number of first-generation scions of Eastern European parentage lived in both the second and third wards. Dr Joseph Kij, who came to Lackawanna as a child in 1902 and has been very active in the Polish community, attributes Gibbons' success in the third ward to the fact that many first-generation Americans of Polish parentage lived there. According to Kij, who also lived in the third ward, the Poles were vehemently opposed to Toomey and supported Gibbons overwhelmingly. Interview with Joseph Kij. Yet, the data are just not available to verify this hypothesis with certainty, and other facts such as election campaigning, degree of company repression, etc., certainly must be considered in explaining Gibbons' margin. See Donald Adams Clark, "Men on Relief in Lackawanna, New York: Social Pathology in a Satellite City", in: The University of Buffalo Studies, XIV (1937), pp. 10607. Ward-by-ward voting data were extracted from Official Canvas for Erie County, General Election, November 4, 1919, Board of Elections. See also, New York State Manuscript Census data, 1915.

\$) Weinstein. The Decline of Socialism in America, op. cit., p. 108. 
tic victories in all four city-council races suggests that most English-speaking workers remained committed to the Democratic Party. The continuation of the ethnic schism is also confirmed by the election results of 1921, in which the new ethnics gained control of the Republican Party while the old immigrants remained Democratic.

In 1921 the Republican Party nominated middle-class ethnics for office: Walter Lohr, a small businessman, ran in the mayoralty race. Candidates for the city council included Rudolph Zahorski, a first-ward grocer; Mark $\mathrm{Kij}$, a baker residing in the second ward; John Drozdowski, a pipe fitter, gained the third-ward nomination; and Robert Avery, another small businessman, ran in the city's "American" fourth ward. The Democrats nominated their usual Irish-American ticket. They chose Mike Mescall as their candidate for Mayor, and James Carey. Tom McGinty, Joe Mahoney and Mike Hughes for City Council.

The Republican Party's nomination of middle-class ethnics killed Gibbons' chances. Drawing heavily upon former Gibbons' supporters, Lohr carried Gibbons' stronghold, the third ward, with 248 votes to 196 for Gibbons and 191 for Mike Mescall. Despite Lohr's strong showing in the third ward, the incumbent, who finished third in the three-way race, had siphoned away enough votes to return the mayoralty to the Democrats. Although voters ousted all incumbents, the election of Republicans Zahorski and Drozdowski adumbrated the decline of the old Democratic machine. Indeed, the 1921 election represented the second phase in the development of Lackawanna's "new politics". The new ethnics had become a significant political force. In 1923, with the Socialists out of all local races, ethnic Republicans gained control of the mayoralty and held it for most of the next twenty-five years.

The existence of conflicts between the old Yankees and new ethnics during the 1919 election raises fundamental questions concerning the premise that cultural diversity fragments the working class, leaving workers as powerless victims before the uncontested power of their corporate employers. In Lackawanna, striking steelworkers defeated the corporatebacked candidates for Mayor even though they did not transcend the ethnic diversity which atomized the working class. If so, it becomes clear that factors other than ethnic fragmentation play a crucial role in the formation of successful protest movements. The Lackawanna experience provides some clues as to what these other factors might be. First, it is unlikely that Gibbons could have won the election if the anti-Toomey protest vote had had somewhere else to go. Once Toomey had captured both the Republican and Democratic nominations, pro-labor anti-Toomey voters could either vote for Gibbons or leave the mayoral line blank. They did 
quite a bit of both. The implications of this are far-reaching. In addition to confirming the importance of the institutional framework within which protest takes place, Gibbons' protest election suggests, as Dawes argues, that the two-party system sometimes serves to defuse anti-corporate protest movements. ${ }^{81}$

A second and perhaps more important lesson of Gibbons' election focuses on the importance of politics. Apparently, the protestors voted because they thought it would make a difference. And they were right. The reader may recall that on the eve of election day the steel strike in Lackawanna was teetering on the verge of collapse. The election of a prolabor Mayor, however, gave new hope to the strikers and re-invigorated their anti-corporate efforts. Within one week after the election, corporate efforts to break the strike began to fizzle. They eventually failed. In late December fewer than 2,000 workers remained in the mills. In January, after the National Committee called off the Great Steel Strike, Lackawanna's steelworkers voted to stay out, and they remained on strike for another six months. Gibbons' ascension to the mayoralty ended the reign of terror, neutralized the municipality's hostility toward the strike, and allowed Lackawanna's strikers to wage their economic struggle against a corporation that lacked the active support of local authorities. In this sense, the workers' political success provided the foundation for their protracted economic struggle.

81 For a more complete discussion see Alan Dawley, Class and Community (Cambridge, Mass., 1976). 